Renewable energy development in rural areas of Iran

Peer-reviewed author version

Afsharzade, Nashmil; Papzan, Abdolhamid; Ashjaee, Mehdi; Delangizan, Sohrab;

VAN PASSEL, Steven \& AZADI, Hossein (2016) Renewable energy development in

rural areas of Iran. In: RENEWABLE \& SUSTAINABLE ENERGY REVIEWS, 65, p. 743-755.

DOI: $10.1016 /$ j.rser.2016.07.042

Handle: http://hdl.handle.net/1942/23991 


\title{
Renewable Energy Development in Rural Areas of Iran
}

\author{
Nashmil Afsharzade ${ }^{1,}$ a Abdolhamid Papzan², Mehdi Ashjaee ${ }^{3}$, Sohrab Delangizan ${ }^{4}$, Steven Van Passel ${ }^{5,6}$, Hossein \\ Azadi $^{7,8}$ \\ ${ }^{1}$ Agricultural Jihad Organization, Kermanshah. Iran. \\ a) Corresponding author, email: nashmilafsharzade@yahoo.com \\ ${ }^{2}$ Department of Agricultural Extension \& Education, Faculty of Agriculture, \\ Razi University, Kermanshah. Iran \\ ${ }^{3}$ Faculty of Mechanical Engineering. University of Tehran, Tehran. Iran. \\ ${ }^{4}$ Department of Economics, Faculty of Social Science, Razi University, Kermanshah. Iran. \\ ${ }^{5}$ Centre for Environmental Sciences, Hasselt University, Hasselt, Belgium. \\ ${ }^{6}$ Department of Engineering Management, University of Antwerp, Antwerpen, Belgium. \\ ${ }^{7}$ Economics and Rural Development, Gembloux Agro-Bio Tech, University of Liège, Liège, Belgium. \\ ${ }^{8}$ Department of Geography, Ghent University, Ghent, Belgium.
}

\begin{abstract}
Iran's energy system is extremely dependent on fossil fuels which, in turn, have led to problems such as fossil fuels depletion, social, economic and environmental damage and territorial imbalance. The country should therefore design a sustainable energy system based on clean energy as well as renewable energy. Accordingly, and given that Iran's rural areas suffer from the unsustainable energy system, it is necessary to integrate renewable energy into comprehensive development programs in general, and into rural development programs, specifically. This review paper answers the following questions: Why is renewable energy important for Iran at national and rural levels? How is renewable energy related to sustainable rural development? and What are the challenges in the promotion of renewable energy technologies in Iran? The paper concludes that although renewable energy has potential for development in Iran's rural areas due to environmental, social and economic advantages, it could face some infrastructural, managerial, socio-cultural and economic challenges. Accordingly, aggressive and innovative policy making is required to meet these challenges.
\end{abstract}

Keywords: Energy consumption, Fossil fuels, Clean energy, Sustainable energy, Sustainable rural development.

\section{Introduction}

Nowadays, global energy systems are highly reliant on fossil fuels. However, in spite of strong economic development emanating from the energy system in the last century, fossil fuel depletion, environmental damage and territorial imbalances [88] have led to a global shift toward clean energy. As Fig.1 shows, the total global investments in clean energy increased from $\$ 54$ billion in 2004 to $\$ 269$ billion in 2012 and the total new global investments in renewable energy increased from \$40 billion in 2004 to $\$ 244$ billion in 2012 (Fig.2). According to the International Energy Agency [41] 
the utilization of renewable energy ${ }^{1}$ will triple between 2008-2035. Also, it is anticipated that the share in renewable electricity production in Middle Eastern regions - the heart of the world's fossil fuel reserves- will amount to $16 \%$ in 2035 [41].

In Iran, unsustainable energy supplies and use coupled with an unreliable and unsecure energy system have had a demanding and lasting impact on economic, social and environmental development [34]. Hence, the country should act in line with the global approach and consider renewable energy, as well as endeavor to restructure and redesign the existing energy systems. Such an approach is imperative, because Iran, as a developing country, is experiencing serious challenges such as the depletion of fossil resources and territorial imbalances that highlight a need to design a sustainable energy pattern based on clean energy. It is therefore necessary to integrate renewable energy into development programs; specifically in rural areas where rural development programs dramatically suffer from unsustainable energy systems despite those areas being among the most important areas in Iran's economy. According to the Statistical Center of Iran (2011), 29\% of the country's population live in rural areas and produce about $11 \%$ of the country's GDP. These areas are also contribute to $23 \%$ of the country's employment and $80 \%$ of the food supply [4].

According to TAVANIR, about $5.5 \%$ of households in villages in Iran's rural areas with less than 20 households still do not have electricity [22]. Also, the average annual cost of energy for rural households and its share in total household expenditure is higher than in urban households [21]. However, it seems that unsuitable access to energy resources and its destructive impacts have inevitably led to some negative consequences; such as deforestation, soil erosion, low soil productivity, the increasing emission of GHG and the spread of various human diseases due to traditional energy systems. Bearing such consequences in mind, the present study was conducted to: i) investigate factors that necessitate the development of renewable energies at national and rural levels, ii) link renewable energy to sustainable rural development, and iii) explore challenges to promote renewable energy technologies in Iran.

\section{The necessity of renewable energy development in Iran}

A review of literature reveals that at national levels, renewable energy development is at least entangled with four key categories as follows: (i) energy consumption, (ii) status of power plants, transmission and distribution grid, (iii) heavy fossil fuel costs, and (iv) the great potential of renewable energy.

Each category includes several factors that are discussed more in the following details.

\subsection{Energy consumption}

Fossil energy carriers provide more than 97\% of the energy in Iran (Fig. 3). The country suffers from undesirable levels energy consumption. As far as energy systems are concerned, even goal-oriented subsidies and increasing energy carriers' prices have not motivated a reduction in energy consumption. According to the Majlis (Iranian Parliament) Research Center [52], both targeted subsidies and rising energy prices have not had significant influence in reducing energy consumption in either urban or rural areas. The amount of energy consumption in Iran is so unbridled that per

\footnotetext{
${ }^{1}$ The IEA's definition of renewable energy sources includes energy generated from solar, wind, biomass, the renewable fraction of municipal waste, geothermal sources, hydropower, tidal, wave resources, biofuels [40].
} 
capita energy consumption in the country is $68 \%$ higher than the global average consumption; i.e. fourteen times higher than Japan, five times higher than India and Pakistan [22].

The sustainability of the energy system could be investigated through macroeconomic energy indicators such as the average annual energy consumption, energy intensity, etc. According to Energy Balances [22], Iran is ranked 13th in the world with regard to the average annual energy consumption which equals to 155 million tons of crude oil. In the country, from 2000 to 2010, the residential and commercial sectors have long been the country's largest energy ${ }^{2}$ user (40\%) followed by the transport and industrial sectors with an average of respectively $28 \%$ and $20 \%$ in the same period [9]. This shows that Iran is facing serious challenges regarding the optimal utilization of hydrocarbon resources, raising the concern about imbalanced energy use and unsustainable energy systems that can lead to unsustainable development. This, in turn, affects different aspects of social, economic and environmental development including livelihoods, access to water, agricultural productivity, health, population levels, education, and gender-related issues.

In Iran, energy intensity defined as the amount of energy used to produce a dollar's worth of economic output (or conversely, the amount of economic output that can be generated by one standardized unit of energy [22] is, on average, seventeen times higher than in Japan, four times higher than in Canada, three and a half times higher than in Turkey, two times higher than in China, and about four to five times higher than the world average [48]. Energy efficiency- as opposed to energy intensity- in Iran, was equal to 522.9 dollars in 2011, while the global average in the same year was 884.0 dollars [22]. As noted above, Iran's economy is highly energy intensive (Fig.4), which along with the low energy prices has resulted in over-consumption of energy and low efficiency. The presence of energy-intensive industries such as metallurgical and petrochemical plants is also contributing factors. According to Helio International [38] energy intensity in Iran is still increasing. Although this may partly be justified as a measure of welfare improvement (in household consumption), mismanagement is undoubtedly the main cause behind the dramatic values of energy intensity [38]. This situation has inundated the country with extreme challenges, because according to many experts, given the highly accelerated energy consumption trend in Iran, if the present trend of energy consumption continues $[76,82,68]$ the country will be a major fossil fuel importer in the next decade (Fig. 5), ending up with huge economic losses due to the loss of the entire oil revenue and cumbersome energy costs.

Since the annual energy demand for meeting the needs of the country's development programs has increased to 2,000-3,000 MW of electricity; the power capacity of the country must increase to 90,000 MW by 2020. It is noteworthy that currently, $98 \%$ of the energy required for electric power plant is supplied by non-renewable fossil fuels [73]. As a result, restructuring and redesigning the energy system in Iran is needed. The renewable energy share in electricity generation in the country is currently about $3 \%$ with a potential to increase to $38 \%$ by 2030 [40]. In other words, Iran's capacity for electricity generation using renewable energy sources, excluding the 9 thousand MW capacity of hydroelectric plants, is presently about $155 \mathrm{MW}$. This includes $3 \%$ of country's electricity production capacity. Wind and geothermal energy have a major contribution with 98 and 55MW, respectively. The contribution of solar energy is minimal [58]. Given that the annual electricity consumption increases over $10 \%$ in Iran, this is an undeniable necessity to pay attention to "energy portfolio" in order to promote energy security. According to Tavanir Company, a total of 205.951 million $\mathrm{kWh}$ of electricity was consumed in Iran in 2014. Of this amount, only 8.6 percent was related to electricity production from nuclear, solar and wind resources. By far, due to the low cost of

\footnotetext{
${ }^{2}$ Including oil, gas, coal and biomass energy.
} 
gas and fuel for thermal and gas power plants, the wind and solar plants were not economically justified. However, the implementation of targeted subsidies phase has got more serious and the price of fuel has approached the real price. Today, therefore, the required costs for the construction and operation of power plants with renewable fuels have economic justifiability. Last year (2014), the capacity of electricity generation increased over 220 MW using clean and renewable sources. The development of renewable energy may reduce greenhouse gas emissions and save the country from heavy international fines. Considering the high potential of renewable power in Iran, it seems that the development of these plants should be accelerated. The most important challenge in this area is the determining the right price for renewable electricity. Apparently, this may not compete with the electricity of thermal power plants with subsidized fuel, but the calculation of fuel price in FOB Persian Gulf and the actual cost of thermal power generation shows that it is economically justified to purchase electricity with higher prices from renewable power plants, particularly wind power plants [58].

\subsection{Status of power plants, transmission and distribution grids}

As mentioned earlier, $98 \%$ of the energy required for the electric power plants is supplied by fossil fuels in Iran [73]. Natural gas is the largest (63.3\%) supplier of fuel in power plants [22]. But given the natural gas shortage during cold seasons, the most critical issue related to electricity generation in these seasons is fuel provision for the power plants. This dependency on natural gas has affected the power generation industry seriously and has led to a constraint in power grid exploitation. According to the National Energy Panel [67], other reasons for shifting energy generation toward renewable energy, are as follows:

- Low efficiency (30\%) of the centralized power system along with transmission and distribution systems. In terms of loss of electricity in distribution network, Iran ranked 84th among 110 countries in 2010. The balance sheet statistics from the Ministry of Energy shows that the total electricity loss in transmission and distribution networks was 18.1 percent in Iran in 2011. This loss increased to 18.7 percent in 2012, though.

In Iran, the total nominal capacity of power plants reached 70 thousand MW in 2013. Despite this power plant capacity, the one percent loss in electricity network implies the loss of at least one percent of power plant capacity. Each one percent loss means the loss of about 300 million dollars of fuel in power plants. The other damage from losses in transmission and distribution networks is the loss of delivered electricity to transmission and distribution networks. In 2014, each percent loss was estimated to be more than 2 billion $\mathrm{kWh}$ [58].

- The need for huge financial resources to develop power plants and the limitation of the number of investors.

- The geographic extent of the country and the heavy economic cost due to the transmission grid extent.

\subsection{Heavy fossil fuel costs}

Extensive pollution is one of the byproducts of this unbridled energy consumption in the country. Iran Carbon Dioxide Emissions in 2009 were 528.6 million of metric tons of $\mathrm{CO}_{2}$, which ranked the country as $10^{\text {th }}$ in the world [25]. It should be noted that the power plants are the 
largest concentrated source of emissions, generating roughly $27.6 \%$ of the nation's total emissions [69].

Some of the extensive economic, social and environmental consequences resulted from the pollution are described as follows:

- Costs of environmental degradation are about $8.8 \%$ of the GDP (\$10,000 million) in 2005 according to the World Bank [99]). It is also predicted that in 2019, the cost of $\mathrm{CO}_{2}$ emission and environmental degradation will increase to $1.36 \%$ [99] and $10.9 \%$ of the GDP, respectively [83, 99].

- Death toll caused by air pollution has been reported to have an economic cost of $\$ 640$ million approximately(equivalent to 0.57 of the GDP). Also, the cost of urban air pollution-related illnesses leveled 260 million dollars ( $0.23 \%$ of GDP) in damage on the country's economy [99].

As mentioned above, the unbridled fossil energy consumption has resulted in undesirable consequences in terms of the environmental performance index (EPI) and the energy architecture performance index (EAPI) which are described as follows.

\subsubsection{Environmental performance index (EPI)}

The EPI ranks countries on 25 performance indicators covering both environmental public health and ecosystem vitality. The main environmental indicators include water resources, air pollution, biodiversity and climate change [101]. According to Yale University [101], based on the EPI, Iran was ranked 114th among 132 countries in 2012, while this ranking was 78th, 67th and 40th, respectively in 2010, 2008 and 2006. The statistics indicate that Iran faces growing environmental challenges that are now more perilous to the country's long-term environmental stability. More than two-thirds of the country's lands (up to 118 million hectares) are rapidly turning into desert [97, 35]. In other words, each year, one percent is being added to the Iran's desert areas [50]. Moreover, water resources are one of the EPI indicators. In the recent decade, groundwater resources have dramatically declined due to over exploitation ${ }^{3}$, especially in the northeast of the country. Based on Iran's Water Resources Management Company (2012), groundwater levels have dropped on average 102 meters in 70 plains [49]. According to Kardowani [46], in arid areas with low levels of groundwater, the fresh water will eventually be replaced by salty water. Hence, the irrigated lands are increasingly threatened by salinization which, in turn, has led to desertification which is a serious problem that country must tackle. Iran's desert land per capita has recently been estimated as two times more than the world average [22]. Besides, conventional power plants use large quantities of water for cooling, washing and cleaning [87]. So, it can be said that if the country continues to use fossil fuel-fired power plants, the groundwater level would decline further and deserts will emerge more rapidly.

\subsubsection{Energy architecture performance index (EAPI)}

${ }^{3}$ Water footprint of Iran is relatively high $\left(1,624 \mathrm{~m}^{3} / \mathrm{cap} / \mathrm{yr}\right)$ partly because of low yields in crop production and partly because of high evapotranspiration. It should be noted that the global water footprint is $7,450 \mathrm{G} \mathrm{m}^{3} / \mathrm{yr}$, which is on average $1,240 \mathrm{~m}^{3} / \mathrm{cap} / \mathrm{yr}$ [39]. 
The EAPI is a global initiative for creating a set of indicators that help to highlight the performance of energy systems of countries. According to the World Economic Forum [100], the EAPI measures the specific contribution of an energy system to three components of the energy triangle: economic growth and development, environmental sustainability, as well as accessibility and security of supply. It comprises 16 indicators aggregated into three baskets related to these three imperatives, in the EAPI ranking in 2013, Iran was ranked 98th among 105 countries followed only by 8 countries including Zambia, Cambodia, Bahrain, Mongolia, Nepal, Mozambique, Lebanon and Tanzania. The unsustainable energy system is one of the most important problems facing this country, so a new energy architecture, as well as the redesign and restructure of the current energy system is necessary to provide a secure, affordable and environmentally sustainable energy.

\subsection{The great potential of renewable energy}

Iran has a great potential of renewable energy sources as seen in the following.

\subsubsection{Solar}

Iran is located in the world's Sun Belt [102]. Solar radiation in Iran is estimated to be between at 1800 to $2200 \mathrm{KWh} / \mathrm{m}^{2}$ per year, which is higher than the global average. An annual average of more than 280 sunny days is reportedly recorded over more than $90 \%$ of Iran's territorial land, which implies a highly significant potential source of energy [3]. Some of the completed solar energy projects in Iran are as follow:

- $10 \mathrm{~kW}$ Photovoltaic Power Plant at "Dorbeed" village in Yazd Province.

- 2 Photovoltaic Power Plant at "Hosseinian" and "Moalleman" village in Semnan Province with the total capacity of $92 \mathrm{~kW}$.

- $250 \mathrm{~kW}$ Solar Power Generator in Shiraz.

- 350 units $\left(1400 \mathrm{~m}^{2}\right)$ Solar Water Heaters.

- P.V. pumping for agricultural use, P.V. electricity generation for a border post and P.V. street lighting.

Some of the ongoing solar energy projects are:

- 1MW Solar Power Thermal Plant under construction in Talegan-Karaj.

- $\quad 45 \mathrm{~kW}$ grid connected P.V. under constructed in Talegan.

- 650 units $\left(2600 \mathrm{~m}^{2}\right)$ Solar Water Heaters for domestic use under construction.

- 2 units $\left(400 \mathrm{~m}^{2}\right)$ Solar Water Heater for village public baths under construction [57].

\subsubsection{Wind}

The potential for wind power generation is estimated to be about 6,500 MW in the eastern and northern parts of the country [62]. These areas are situated in the path of strong wind flows and have a lot of potential for installing wind turbines and producing the electric power. The central and southern regions do not have the same potential, but it is possible to install wind turbines to pump water in these areas [2]. Presently, the capacity of installed wind farms in Iran is approaching $75 \mathrm{MW}$, mainly located at two northern sites, the Manjil and Roodbar wind farms, where the converted energy is fed to the local grid. These wind farms are planned to be further enhanced to $90 \mathrm{MW}$. Moreover, installation of another 60MW wind farm is also under consideration [15].

\subsubsection{Hydropower}


The potential for Iranian hydropower is estimated at 50,000 MW; of which around 7,670 MW are already in operation and about 6,600 MW are under construction. Also, it is possible to install micro hydropower plants in over 3000 spots in Iran [33, 56, 20]. Additionally, according to [31] the finding of several preliminary studies suggest that approximately 2700 villages which are mainly situated in the northern, western, and central provinces in Iran have the potential for hydropower within a radius of $10 \mathrm{~km}$ in their vicinity. In Iran, of the operative plants, a number of big, medium, small and mini/macro plants are 6,12,12 and 12 respectively. The big hydro plants, ranging above $100 \mathrm{MW}$, cover more than $90 \%$ of the present installed capacity. Further, it is planned to construct more big and medium hydro units, enhancing the present capacity behind 25,000 MW. Presently, there are only 12 small hydro power systems with a total installed capacity of 46.5MW and 12 Mini/Macro hydro systems with a total capacity of around 2.9MW [33]. The available hydro potential from Mini/Macro systems is not yet accurately estimated and these vast potentials of hydro power, like other renewable energies, are not effectively utilized and are even deprived of any further extensive planning. The machineries and know the simplicity of such systems and how they can be locally be manufactured to the extent that, if the planning is focused on this field, the power derived will be amazing and Iran, like China, can become one of the top utilizers of such hydro potentials, making the country capable of even exporting this technology to neighboring countries.

\subsubsection{Biomass}

In Iran domestic and industrial sewage/waste, animal dung/waste, and the $80 \%$ of garbage and left over of agricultural products are the main sources of biogas energy [33]. The preliminary studies show that the recoverable energy rate from biomass resources in Iran in 2008 was equivalent to 150 million barrels of petroleum with a share of agriculture and forest of 50\%, $15 \%$ municipal wastes, 23\% manure/dung, 2\% municipal sewages, and 10\% alimental industry [88]. According to Samadi et al. [78], industrial cattle manure, could produce 760 million $\mathrm{m}^{3}$ of biogas - equivalent to 239.2 million barrels of crude oil that could supply more than $97 \%$ of the energy required by the agricultural sector on an annual basis in Iran. It could generate 37,000 GWH of electricity and 8,600 PJ of heat. In other words, it is possible to supply $6 \%$ of the total electricity consumption of the agricultural sector in the country by using this biomass technology. In addition to these advantages, biogas production in the Iranian rural area is important, not only have the agricultural wastes such as cereals residues not been used as a beneficial product, but also a large portion of these residues are burnt on-farm, primarily to clear the field for sowing of the succeeding crop. However, according to Bahrami and Abbaszadeh [15], the nameplate power of biogas power plants in Iran is $1.860 \mathrm{MW}$ and the total installed capacity is $1.665 \mathrm{MW}$. Private sectors have already signed contracts to build more than $600 \mathrm{MW}$ of biomass systems in the country.

\subsubsection{Geothermal}

Iran is located on the global geothermal belt, indicated by many warm water streams, volcanoes and regular ground movements [33]. Based on an accurate digital geothermal potential map in 2007, 8.8\% of the country was prospected as potential geothermal areas in 18 promising fields [66]. Also, the studies conducted through well logging in Iran indicate 14 viable regions that have already been specified. In one of these regions alone, there is a capacity of $250 \mathrm{MW}$ of electric power generation attained by digging three wells [15]. According to [64], Iran has substantial geothermal potential in its northern provinces. In the country, two geothermal projects are being constructed in Ardabil Province at present. By the end of 2010, the Meshkinshahr geothermal power plant project revealed a progress rate of 50\%. Similarly, the package construction project in Ardabil revealed a 32\% rate of progress. 
Due to financial hardship in the Fourth Development Program, the completion of these projects was extended to the end of the Fifth Development Program [15].

\subsubsection{Marine}

Due to the long coastline along the Persian Gulf and the Caspian Sea, "thermal, tidal, and wave" resources of energy are abundantly available in Iran. With up to $2700 \mathrm{~km}$ of shoreline and several big rivers, Iran has great potential to develop marine energy power plants [79]. It is noteworthy that the key characteristic of sea waves is their high energy density, which is the highest among renewable energy sources [19]. However, it seems that Iran's potential for renewable energy can catalyze rural development in the country. Linking renewable energy and sustainable rural development in Iran are discussed more in the following details:

\section{Renewable energy and sustainable rural development in Iran}

As mentioned earlier, it is necessary to take into account Iran's approach to renewable energy (RE) at national, regional and strategic levels. In rural and especially in remote areas, the RE development is inevitable because of unsuitable access to energy resources and its devastating consequences. The dispersion of villages, lack of access to suitable roads, the high price of fossil fuels compared to the villagers` income, and high costs of fuel transportation have resulted in an increasing consumption of wood, bushes, thorns and animal wastes. Accordingly, the Forests, Range and Watershed Management Organization has conducted several studies on the replacement of biomass fuels. From 1994 to 2010, approximately 50\% of firewood, biomass and thorn consumption in both rural and nomadic areas decreased significantly. However, this decreasing trend changed completely since the implementation of the Iran's subsidy reform. It should be noted that the Iranian subsidy reform plan was approved by the Iranian Parliament in 2010. The goal of the plan was to replace subsidies on food and energy (80\% of total) with targeted social assistance, in accordance with a five-year economic development plan and to move towards free market prices in a five-year period. However, as mentioned above, this plan led to an increase in the firewood, biomass and thorn consumption. For example, the wood, shrub, thorn and animal waste consumption increased by $10 \%$ in the Northern provinces and 30\% in other provinces during 2011, compared with the corresponding period in 2010. Moreover, fuel shortage has led to wood smuggling and the cutting of trees by local communities. According to the Ministry of Energy, in 2011, compared to 2010, the discovered and confiscated charcoal shipments increased to $32.9 \%$. This trend has inevitably led to some negative consequences such as: deforestation, soil erosion, low soil productivity, increasing GHG emissions and various human diseases due to traditional energy systems [46].

The study of expenditure deciles shows that in rural and urban areas, the share of energy costs in the total household expenditure is higher for poorer households [21]. This result shows that the lower deciles of society - due to the large share of energy costs in their portfolio compared to higher deciles - have the disadvantage of targeted subsidies. Based on the Energy Balance [21], the average annual cost of energy for rural households and its share in the total household expenditure in 2010 was higher than for urban households. Obviously, this shows that energy is not a luxury good reserved only for the rich, but it is an essential precondition for fulfilling basic human needs of the poor. As earlier mentioned, about 5.5 percent of households in villages with less than 20 households still do not have electricity in rural Iranian areas [22]. In other words, this population is deprived of all facilities related to electricity, such as telecommunications, education, and health, etc. In these areas, 
because of limited infrastructure, grid extension and providing diesel supplies is difficult. Table 1 shows the rural electrification situation in Iran according to MOE [57].

Table 1: The rural electrification situation

\begin{tabular}{|c|c|c|c|c|c|c|}
\hline \multirow[t]{2}{*}{ Subject } & \multicolumn{2}{|c|}{ In the country } & \multicolumn{2}{|c|}{ With national grid } & \multicolumn{2}{|c|}{ Percent of electrification } \\
\hline & Villages & family & Villages & family & Villages & family \\
\hline $\begin{array}{l}\text { More } \\
\text { than } 20 \\
\text { family }\end{array}$ & 41636 & 4123101 & 41636 & 4123101 & 100 & 100 \\
\hline $\begin{array}{l}\text { Less } \\
\text { than } 20 \\
\text { family }\end{array}$ & 13093 & 146121 & 12480 & 138022 & 88.6 & 94.5 \\
\hline total & 55729 & 4269222 & 54116 & 4261123 & 97.1 & 99.8 \\
\hline
\end{tabular}

Fortunately, as mentioned above, Iran has access to significant potential resources of renewable energy that could help provide sustainable energy in these regions as seen in the installed capacity of Solar PV in rural areas in Iran in Table 2 [57]. Moreover, it seems that the development of renewable energy in rural areas in Iran is possible because the general policies and regulatory incentives support it. Main policies for renewable energy in Iran are as follow:

- Supporting private sector for dissemination of RE applications that are approaching economic viability, such as wind, geothermal and biomass energy.

- Supporting manufacturers for transferring and localization of RE technologies which are expected to become competitive in medium terms, e.g. PV systems and solar thermal power plants.

- Supporting the research centers to expand the research programs for RE technologies that are becoming competitive in longer than 10 years period.

- Providing sustainable and accessible energy to the poor and isolated areas.

With regard to the implementation of these policies, regulatory incentives are provided by the government in Iran. In other words, from a legal framework, the country benefits from private sector investment in RE. Article 62 of The Law of Regulation a part of the Governmental Financial Provisions. This is a very similar law to the Feed-in-Tariff laws, used in European countries. This concept allows the most feasible renewable energy source to develop first. In the instruction MOE has been recognized as the responsible executive authority of the program. With further approval by the Cabinet Council, in 2008, the price set at: 1300 Rials (0.13\$) per kWh for peak \& normal load hours, and 900 Rials $(0.09 \$)$ per $\mathrm{kWh}$ for off-peak hours (4 hours a day)[57]. In 2013 the feed-in rate for regular consumption was decided to be $4440 \mathrm{IRR} / \mathrm{kWh}$. This amount equals approximately US \$ 0.178 . It should be noted that in 2001 the feed-in rates were US $\$ 0.067 / \mathrm{kWh}$ in peak and regular consumption hours and US $\$ 0.047 / \mathrm{kWh}$ in off-peak times. Also based on article 139, the government 
is obligated to plan for $5000 \mathrm{MW}$ of power by providing financial support to public and privet sectors during the fifth development program [58].

Table 2: Installed Capacity of Solar PV in Rural Areas in Iran

\begin{tabular}{|c|c|c|c|}
\hline Under implementation & Completed & Province & No \\
\hline 80 & 70 & East Azerbaijan & 1 \\
\hline--- & 32 & Ardebil & 2 \\
\hline 34 & --- & Esfahan & 3 \\
\hline 47 & 19 & Boshehr & 4 \\
\hline--- & 48 & Charmahal va Bakhtiyari & 5 \\
\hline--- & 101 & Lorestan & 6 \\
\hline 26 & ---- & Khorasan Razavi & 7 \\
\hline 116 & 30 & South Khorasan & 8 \\
\hline 27 & ---- & North Khorasan & 9 \\
\hline 10 & 70 & Khozestan & 10 \\
\hline--- & 78 & Zanjan & 11 \\
\hline--- & 29 & Semnan & 12 \\
\hline--- & 39 & Ghazvin & 13 \\
\hline 96 & ----- & Ilam & 14 \\
\hline--- & 25 & Kurdistan & \\
\hline--- & 43 & Kermanshah & 15 \\
\hline 15 & 43 & Fars & 16 \\
\hline 10 & 18 & Kerman & 17 \\
\hline 54 & 5 & Gilan & 18 \\
\hline--- & 24 & Mazandaran & 19 \\
\hline 3 & ----- & Golestan & 20 \\
\hline 36 & --- & Hamedan & 21 \\
\hline $554 \mathrm{KW}$ & $674 \mathrm{KW}$ & \multicolumn{2}{|l|}{ Total } \\
\hline
\end{tabular}

Devastation of natural resources will destroy real amenities. The level of harmful gases needs to be reduced and the wealth of nature needs to be protected. Moreover, the process of achieving welfare of the vulnerable populations needs to be enabled and accelerated based on the least $\mathrm{CO}_{2}$ emissions.

Achieving any of these goals would not be possible without a clean energy revolution. Consequently, it can be claimed that the energy sector is a "strategic sector" to achieve sustainable development, because this sector is one of the major $\mathrm{CO}_{2}$ producers. It should be noted that $\mathrm{CO}_{2}$ is responsibe for nearly $58.8 \%$ of the global warming and climate changes [74]. The consequences of climate change are intermingled with the changing human geography in the Earth [96]. Based on the 
article $4.8^{4}$ of the Convention on Climate Change, Iran is amongst the countries affected by climate change due to arid and semi-arid weather and poor forest cover. The country is also threatened by natural disasters such as floods, droughts, desertification and outbreaks of pests in the agricultural sector that are often associated with climate changes [16]. It is clear that climate change intensifies drought. Drought is one of the main challenges facing rural people in Iran, since based on the Ministry of Energy, about 290 out of 609 plains are categorized as "forbidden plains" [65] and nearly $92 \%$ of arable - horticultural crops are obtained from irrigated land [59]. Thus, it can be said that any water stress and climate change would have a negative impact on the agricultural production and food security, and will be a big blow to the agro-based Iranian rural economy. According to [102], reducing one millimeter of rainfall causes around 15-20 million dollars damage to the agricultural sector. In Iran, the agricultural sector provides more than $80 \%$ of food products and therefore, food security is, to a great extent, dependent on agriculture which, in turn, relies on exhaustible fossil resources. Since, petroleum products supply $71 \%$ of energy demand in the agricultural sector and the share of gas oil in these products is around 97\% [13], the system is unreliable, unsecure and unsustainable. For example, this sector produces 10-12\% of the annual greenhouse gas emissions in Iran [81]. This emission has imposed a heavy economic and social burden on the country. According to [69], the social costs of fossil fuels and electrical energy consumption in the agricultural sector of Iran in 2007 were about \$410 million. According to [8], social costs related to greenhouse gas emissions and air pollution have been higher than the added value of the agriculture sector during 1997-2007. It should be noted that the energy consumption of the agricultural sector increased from 265.1 PJ in 1997 to $411.2 \mathrm{PJ}$ in 2007. This situation necessitates the replacement of obsolete machinery, accompanied by the usage of higher level technology and the management of an alternative and clean energy supply in this sector. Overall, it seems that renewable energy due to its capacity in job creation, diversifying income sources and use of local capacities, is a better alternative to replace fossil energy in rural areas and to move toward designing native rural development patterns. Diversifying the income sources in Iranian rural areas is very important because these areas suffer from a heavy dependency on agriculture, and very small diversification in the rural economy [7] as well as land fragmentation. According to Mirak Zade et al. [61], in Iran, $81 \%$ of the farms are less than 5 hectares in size, and cover only $38.7 \%$ of the total farm area. As a result, rural and agricultural sectors are facing low income and low productivity. Also, soil erosion, deforestation, social inequality, seasonal migration, and the decline in groundwater aquifers are all major negative consequences impinged on villagers. According to Lashkari Pour [50], land subsidence along with a decline in groundwater levels in many aquifers have been reported and are caused by the uncontrolled harvesting of groundwater for irrigation purposes in some provinces of Iran in recent years.

Another challenge, deforestation, is one of the main drivers of land use changes and is considered as the biggest threat to global biodiversity [77]. Deforestation is the second largest anthropogenic source of carbon dioxide to the atmosphere, after fossil fuel combustion [98] that directly contributes to the global warming. According to Emadodin [24] deforestation in Iran has been appeared more rapidly in the past 50 years than any time in the country's history. Also, the need to increase the agricultural production due to population growth and raising the standard of living would cause the continuation and acceleration of the forest destruction. Obviously this situation has put pressure on

${ }^{4}$ Negotiations on the adverse effects/impacts issue of climate change revolve around Articles 4.8 and 4.9 of the UNFCCC and Article 3.14 of its Kyoto Protocol [17].

${ }^{5}$ The withdrawal of water in the plains that was forbidden by order. In Iran, less than 50 plains are in good condition in terms of water supply[57]. 
natural resources [24]. According to Bahrami et al. [14], the natural forests in Iran have reduced from 19 million hectares in the 1950s to 12.4 million hectares in the 1990s. Also, during the past 50 years, the amount of Iran's cultivated land has grown by more than five times, i.e., from 2.6 million hectares to 24.5 million hectares [14].

In Iran, according to the General Director of the Forest Department of Forest, Range land and Watershed Organization (2013), presently, one million hectares (one-sixth of Zagros forests) is infected by Oak Charcoal, of which 300,000 are badly infested. Critical areas are mainly marginal or peripheral forests, where tropical zones ended and temperate regions started. This shows that climate change has an impact on the severity of disease [70]. According to Ahmadi et al. [1], during the last ten years, climate change has occurred in Zagros forests which have resulted in drought stress, subsequently extending desert areas followed by storms, which are associated with fine dust phenomenon. This phenomenon has caused the reduction of photosynthesis in the forest's trees, which makes them more vulnerable to the disease [1]. Based on the National Director of the Central Zagros Project Protect (2013), in the past four years, 10\% of Zagros forests have been destroyed. Thus, if the current trend continues, these forests in the next five years will completely perish and will turn into deserts [44]. Meanwhile, $40 \%$ of the country's water resources are provided by 6 million hectares of the Zagros forests [70]. Also, large numbers of nomads and villagers living in the Zagros region are more or less, dependent on these forests.

As for biomass consumption, it should be noted that: 1) indoor pollution due to biomass consumption affects everyone's health, especially women and children, 2) One cannot destroy forest and the same time hope to cultivate it, because at best, one can cultivate "trees", not the "forest"6. It is obvious that loss of biodiversity is another concern relating to deforestation, because it ultimately leads to "unsustainable" ecosystems. The forest per capita in Iran is 0.17 ha and in the world is 0.62 ha [22]. It is clear that underlying causes of deforestation should be identified and dealt with.

"Poverty" is one of the main factors of deforestation."Poverty" along with "energy security" and "climate change" are known as the three main challenges in the world [27]. The poverty is more common in rural rather than among urban communities when considering the total population of Iran [48]. Today, the poorest people largely live in the ever changing environment; i.e., poverty has pushed the poor into marginal and environmentally vulnerable, remote and marginal areas in growing cities [37,12]. Poverty is the greatest threat to political stability, social cohesion and the environmental health of the planet. So, there is a need for comprehensive condition-based and problem-solving strategies to tackle poverty. Obviously, strategies such as economic growth, development and environmental ethics expansion, etc, are effective solutions to poverty reduction, but it would not be possible without energy, particularly the clean ones. Perhaps this is the reason for the UN General Assembly's declaration: to overcome poverty and save the planet, we can and must achieve sustainable energy worldwide by 2030 [94]. It seems that the linkage between energy and poverty reduction calls for urgent action for a comprehensive or cultural, social, economic and environmental development. Obviously, this kind of development would not be feasible through "intention" only. It requires dealing with the infrastructure, creative destruction, with bridging

${ }^{6}$ This means that when an ecosystem, such as forests, is degraded, it may be possible to revive a part of it, for example, by planting trees. But since an ecosystem is a collection of living organisms in conjunction with nonliving components, and these biotic and abiotic components are linked together; therefore, by planting trees, restoration of all ecosystem components will not be possible. In other word, the restored ecosystem may not necessarily recover its former state. 
cultural, structural and organizational, etc barriers and replacing developmental thinking. These changes also hinge on investment, training, advertising, networking and so on. In addition, all of these, more or less, depend on energy, directly or indirectly. However, considerable dependence of rural people on environmental resources and improving environmental conditions is crucial. Rural areas, compared to urban ones have some relative advantages, such as access to more open space to establish solar and wind farms. Also, massive amounts of biomass resources including agricultural and forestry waste (equivalent to 74 million barrels of crude oil) and livestock waste (equivalent to 36 million barrels of crude oil) are being produced in rural areas [71]. It is very important that based on the latest published report by the National Iranian Gas Company, only about $7.18 \%$ of rural areas (about 4500 villages) in Iran have access to the gas network [60].

\section{Challenges in the promotion of renewable energy technologies in Iran}

Barriers hindering the expansion of Renewable Energy Technologies (RETs) still remain an important challenge to stakeholders involved in the promotion of RE resources in developing countries such as Iran. In this respect, some studies were carried out. For instance, [11] stated that Iran lacks policy frameworks stipulating provision of energy for sustainable development and RETs promotion in the country. She argues that there is (i) lack of infrastructure, capital, and knowledge about RE potential, (ii) insufficient social and environmental policies and programs to encourage their use/ implementation, (iii) lack of training, maintenance and capacity to purchase the technology, and that (iv) the tradition of technical standards exert severe restrictions on the rapid expansion of RETs. Kardoni [45] believed that, there are several challenges for the development of renewable energy in developing countries including Iran. One of these challenges is the lack of social acceptance and awareness, a point emphasized by several studies as a serious obstacle. Noorolahi and Yosefi [66] stated that changes in the current regulation of the energy sector, legislation supportive rules of renewable energy, training and development of human resources, creating the necessary motivation to keep experienced and qualified manpower and planning for technology transfer during international agreements for current projects are of great importance to achieve sustainable development goals in terms of energy resources. According to [52], the main challenges facing the RE development in Iran are the low price of conventional energy compared to renewable energy and the lack of consensus about the importance of investment in renewable energy sources among authorities and policy makers that, in turn, ends up with lacking a rigorous plan for renewable energy. Also, transaction cost, red tape, and uncertainty in policy change and implementation increase risk premiums for the renewable energy project, diminishing the incentives provided by Iran's feed - in tariff law. This is subjected to government approval and therefore reduces the attractive potentials of the RE investment in Iran. Consequently, the encouragement packages of the government cannot entice investors. Hence, there are gaps between investors' expectations and governmental policies. Aslani et al. [10] also believed that the lack of investor's interest in RE development is one of the great challenges in implementing them. Based on the Ministry of Energy [57], RE development is facing many challenges in Iran, including lack of national and local laws enacted for the development of renewable sources, lack of integrated management of skilled, qualified and trained personnel in the underlying organizations, weakness in technology transfer, even in the case of signed contracts with foreign countries, weaknesses in the development of higher education and academic fields related to RE, lack of educational and vocational courses about REs, lack of national and local laws to stimulate the development of renewable energy technologies and markets, lack of willingness of private investors to enter the field, the existence of cheap and accessible fossil fuels, lack of a comprehensive national codification, and a shortage of funding for projects implementation, in the contract signature between contractor, consultants and project managers. In Iran, also based on [58] there is no specific work in 
relation to energy storage projects and the ongoing projects in the country are only academic studies. As mentioned earlier, a stable and reliable energy supply is a major challenge in some of the sparsely populated areas in the country. Introducing more renewable energy in these areas requires energy storage solutions and better connections between power grids. In Iran, since energy storage is the last step after installation of especially solar energy systems and due to very low development of these systems, storage development of technologies has been neglected. However, it seems that the sevenclassification of barriers of Ansari et al. [6] to the extension of renewable energies is more comprehensive. These categories are as follows: policy making, economic, social, technical, managerial, educational and extensional.

As mentioned earlier, although there exists a great potential for renewable energy in Iran, the share of RE in the energy supply is only one percent. This shows that Iran is facing a series of challenges with RE development. It seems that innovative and aggressive policy making is required to support the replacement of fossil fuels with renewable energy. Some successful policies that are applicable to Iran are assessed below.

\section{International Policies to Promote Renewable Energy}

The rapid growth of renewable energy in Germany and other European countries is due to the proactive European and national policies aimed at directly increasing the share of renewable production in their energy mixes through a variety of generous subsidy programs. Based on [103], the main support policies for RES electricity in the EU Member States is as follows: Feed-in tariffs: Feed-in premiums, Quota obligations with tradable green certificates, Loan guarantee, Soft loans, Investment grants, Tax incentives, Tendering schemes. Others which are also very relevant are: Permitting procedures, Grid access and operation, Power market design and structure, R\&D, industrial policy. Main support policies for RES heat in EU are as below: Investment grants, Tax exemptions and other fiscal incentives, Use obligations. In Germany, as one of the most developed countries in the field of renewable energy, The German Renewable Energy Act (ErneuerbareEnergien-Gesetz, EEG) is a law that came into force in 2000 and introduced FITs as the main mechanism to encourage and finance renewable energy projects. The EEG can be seen as the starting point of a tremendous boost of renewable energy in Germany. The purpose of the EEG is to promote electricity generated from renewable (hydropower, landfill gas, mine gas, sewage gas, biomass, geothermal, wind and solar). Due to changes in market conditions as well as the state of renewable energy in Germany, this law was reformed several times (EEG 2004, 2009, and 2012) and ongoing modifications are needed to keep the development of renewable energy up to date and improve its efficiency and impact.

The main four provisions of the EEG are:

1. Investment protection through guaranteed feed-in tariffs (FITs). Owners of new plants receive a fixed rate, the FIT, for every $\mathrm{kWh}$ of renewable energy they generate. The FIT depends on the specific year a plant goes online, its size and technology, and is guaranteed for 20 years.

2 . Guaranteed interconnection to the grid for renewable energy resources. Every new plant which generates renewable energy gets a preferential treatment over conventional sources by the network operator for feeding "green" electricity into the grid.

3 . Decreasing FITs/digressive rates: Every year, the FIT rate decreases for new plants by a fixed percentage (digression rate). Initially, the digression intended to give renewable owners an incentive to lower the costs.

4 . Socialized and financed by customers, not the government. The FIT is not paid with Government funding, but instead is completely financed by markets and consumers. 
Renewable generation is sold into wholesale markets and receives the market price. The difference between the market price and the government set, predetermined FIT, is paid for by consumers as part of their electricity bills. This portion is called the EEG levy or renewable energy levy (or surcharge). The levy is not applied equally to all consumer types. Industrial consumers pay only a fraction or, in the case of energy intensive industries, are completely exempted [106].

In the United States, state renewable energy policies are usually grouped in two categories. The first category provides financial incentives to encourage renewable energy. These include tax incentives, grants, loans, rebates and production incentives. The second category contains rules and regulations, which mandate a certain action from an obligated entity. Included within this category are Renewable Portfolio Standards, Mandatory Green Power Options, and fuel disclosure rules [93]. In 2007, all but three states (Alabama, Alaska and Mississippi) had implemented at least one of these policies, and four states (Colorado, Iowa, Oregon and Washington) had established all four policies.

Since the early 2000s, China has aligned its national renewable energy policies with three core principles that have contributed significantly to the current prosperity of the renewable energy sector:

-Building up a national producer and consumer base: Strengthening domestic markets in relation to both supply with and demand for renewable energy and related technology is crucial for long-term business development. Initially, the Government imported wind turbines and other key parts but later initiated support for building a domestic industry.

-Protecting green technology markets in the early development stages: Vulnerable new technology markets, especially in emerging and developing economies facing global competition from industrialized nations, need to be protected during the initial market introduction phase. Policymakers implemented domestic purchasing and production requirements, which were abolished once the wind industry was strong enough to face global competition.

- Setting ambitious but achievable goals: Policymakers did not lose sight of their initial intention to introduce renewable energy regulations and tried to set renewable energy goals as high as the Chinese capacities permitted. When the first wind power goal of installing 5GW by 2010 was achieved ahead of time, the policymakers decided to raise the bar and changed it to 10 GW [95]. However, based on the successful experiences mentioned above it seems that strong but flexible regulations are the best facilitator for renewable energies development for developing countries such as Iran. In other words, a low carbon development path that fosters renewable energy needs a set of supporting laws.

\section{Discussion and conclusion}

The amount of energy consumption, status of power plants, transmission and distribution networks and heavy fossil fuel costs, suitable conditions for renewable energy exploitation, development of clean energy such as renewable energy are all major concerns in Iran's energy sector, especially in the rural areas. Approaches to small-scale technologies such as RE technologies in Iran can have several advantages at global, national, and local levels as discussed below.

\subsection{Global level}

Nowadays, the environment has been the motivating concern for many public actions towards mitigating and adapting to climate change, but this is not just an environmental issue. There is a 
strong connection between climate change and issues of poverty, housing, health, security and wellbeing, all of which are of concern to so many people [36]. As mentioned before, Iran is among the top ten GHG emitting countries in the world [41]. Recently, the potential threat of global climate change has increased, and fossil fuel usage has had the highest contribution to the GHG emission. Obviously, clean energy is a key element in the effort to mitigate climate change. So, the usage of renewable energy as a clean and sustainable energy in Iran contributes to mitigate climate change as a global concern as well, according to German Watch and Climate Action Network Europe [29] based on the Climate Change Performance Index (CCPI), Iran was ranked $60^{\text {th }}$ among 61 countries in 2013. The CCPI is an instrument designed to enhance transparency in international climate politics. Its aim is to put political and social pressure on those countries which have, until now, failed to take ambitious action on climate protection. It also aims to highlight those countries with the best-practice climate policies. The CCPI include: emission levels, development of emission, renewable energies, efficiency and climate policy. According to SUNA [88], some solar experts claimed that ideally, if Iran equips its desert area with radiant energy receiver systems, the country could provide the energy requirements for a wide range of the Middle East countries and would be able to launch the export of electricity [88]. Access to renewable energy also helps the country contribute the achievement the Millennium Development Goals(MDGs). Currently 1.4 billion people lack access to electricity and 2.7 billion people rely on traditional biomass for cooking in developing countries [95]. According to Shukla [83], access to electricity may not show direct linkages with the MDGs but supports in their achievement. In other words, access to electricity is positively associated with development goals, in general. Based on the Renewable Energy Policy Network for the 21st Century [74], access to electricity reduces the share of household income spent on cooking, lighting, and space heating, improves ability to cook staple foods, reduces post-harvest losses through better preservation, enables irrigation to increase food production and access to nutrition, enables enterprise development, utilizes locally available resources, creates jobs, generates light to permit income generation beyond daylight, powers machinery to increase productivity and eradicates extreme poverty and hunger as Goal 1 of MDGs. Goal 2, universal primary education, is more accessible by providing some infrastructures such as light for reading or studying beyond daylight and creating a more child-friendly environment (access to clean water, sanitation, lighting, and space heating/cooling). Providing lighting in schools can improve attendance and reduce drop-out rates, which can help retain teachers, enabling access to media and communications that increase educational opportunities and reducing space heating/cooling costs and thus school fees. Additionally, easy access to energy helps promote gender equality (Goal3) by freeing women's time from survival activities, allowing opportunities for income generation, reducing exposure to indoor air pollution and improving health, lighting streets to improve women's safety and providing lighting for home study and the possibility of holding evening classes. Health Goals 4, 5, 6 are more attainable with electrical energy because it contributes to providing access to better medical facilities for maternal care, allowing for the refrigeration of medicine, equipment sterilization, and safe disposal by incineration and facilitating development, manufacture, and distribution of drugs, providing access to health education media, reducing exposure to indoor air pollution as well as improving health and enabling access to the latest medicines/expertise through renewable energy-based telemedicine systems. Finally, environmental sustainability- Goal7- is more accessible by boosting agricultural productivity, increasing quality instead of quantity of cultivated land, reducing deforestation for traditional fuels, reducing erosion and desertification, reducing greenhouse gas emissions and restoring ecosystem integrity through land management.

\subsection{National level}


The approach to small-scale technologies such as RE technologies is equal to the approach to the Distributed Generation(DG) systems. According to the National Energy Panel [66], the advantages of DG systems for Iran at national level could be as follows:

- $500 \%$ increase in the passive defense index;

- 2-3 fold increase in the efficiency of the electric power industry;

- $30 \%$ reduction in the final energy consumption;

- Reducing power dissipation during on-peak times;

- Increasing efficiency in centralized power system from approximately 30 to 70-90\%;

- Eliminating the $30 \%$ investment cost in transmission and super distribution network with a focus on distribution system;

- Facilitating the operation of the article $44^{7}$ of the constitution;

- Releasing the transmission and super distribution network capacity;

- Reducing capacity in the large power plants;

- Electrification to isolated areas;

- Increasing network security;

- Pollutants reduction;

- Preservation of the fossil resources and their conversion into high value-added petrochemical derivatives.

These positive effects are, considerably, important, because studies such as [34] show that both supply and use of energy are unsustainable in Iran. Also, the oil industry is very important for Iran's economy, since it is ranked as the first basic income (revenue) for the country's economy. Secondly, the oil industry is one of the most important industrial sectors which, thirdly, accounts for more than $95 \%$ of primary energy supply [72]. In a different sense, according to the Wuppertal Institute and Iranian Experts, in 2005, if 25\% of households in Tehran switched their current hot water supply methods to solar panels, and even if state subsidies completely covered the costs for an amortization period of 25 years, Iran's economy would benefit from an additional economic profit of USD 1.8 billion for the state budget and simultaneously reduce $\mathrm{CO}_{2}$ emissions by 503,000 tons per year [55]. This indicates the potential of renewable energy for economic benefits and environmental protection.

As Atabi [11] stated, in developed and developing countries, the development of renewable energy technology (RET) is viewed both as a process of diversification of energy sources and as a creation of an alternative energy options that will help dealing with global climate change and creating energy security for future generations. However, according to Lethtenbohmer et al.[51] some disagree with the initial claim that Iran has abundant fossil energy resources, thus investment in renewable energy is not a priority. They also argue that since RET are still immature, it will be more beneficial to wait until the technology matures enough to compete with conventional energy resources. Iran's oil capital, Ahwaz, ranked as the most polluted city in the world, is facing acid rain [104]. The questions that should be addressed by the renewable energy opponents are: How will/can Iranian policy makers and practitioners deal with probable issues such as acid rain without a clean energy approach? What can they do to focus on a centralized model of energy production that requires plenty of water to combat the scourge of the dramatic

\footnotetext{
${ }^{7}$ According to the Article 44 of the Iranian Constitution, the economy of Iran is to consist of three sectors: state, cooperative, and private; and is to be based on systematic and sound planning. This article has been amended in 2004 to allow for the Privatization of the Iranian economy. It should be noted that currently only $9 \%$ of electricity in the country is supplied by large private power plants [66].
} 
drop in groundwater aquifers, death of plains and desertification? Given that oil is the main source of foreign exchange for the country; will there be enough oil to import green technologies in next decades? Furthermore, since Iran is ranked 7th in the world in terms of new and renewable energies, is it not better for the country to be in line with the world efforts to curb the world environmental problems and be an exporter of green technology, instead of and not as an importer?

\subsection{Local level}

At the rural level, the utilization of renewable energy is completely justified due to the following facts:

- Comparative advantage for renewable energy exploitation in rural areas [69].

- Current deprivation in rural areas and small share of fossil energy [69].

- Lack of access to the grid in remote areas and the high cost of transmission and maintenance [32].

- Changing previous energy consumers to energy producers [32].

- No need for integrating small-scattered villages for electrification ${ }^{8}[80]$.

- Extensive unemployment in rural areas and potential of renewable energy for job creation.

Finally, it should be noted that due to special characteristics of the RE such as positive impacts on increasing agricultural productivity, higher potential in job creation [85, 94], renewable energy could be considered as an approach to reduce rural communities' challenges such as gender equality, empowerment and sustainable livelihoods in disaster-prone countries like Iran.

In Iran, the most important documents such as "Iran's Outlook of 1404" and law programs also emphasize on improving livelihoods and the social and economic development and poverty alleviation are the overriding priorities of the country. Obviously, access to modern energy services is fundamental for fulfilling basic social needs, driving economic growth and fueling human development. Due to energy services, this has an effect on productivity, health, education, safe water and communication services. Modern services such as electricity, natural gas, modern cooking fuel and mechanical power are necessary for improving health and education and providing better access to information and agricultural productivity [28]. It is clear that sustainable renewable energy will speed up the provision of modern energy and help achieve important rural development goals such as empowerment and sustainable livelihoods in these areas and at the same time, can deal with climate change.

In summary, it seems that regarding the features of the Iranian agricultural and rural sector, renewable energy can meet economic, social and environmental challenges in rural areas much better than other types of energy. However, because of the desirable renewable energy resources and overall conditions in this country, it is possible to approach RE as an environmentally friendly technology. On the one hand, the reduction of $\mathrm{CO}_{2}$ takes place, and on the other, we can enjoy some advantages such as, creating employment for people, better health, reduction of the use of fossil fuel resources, reduction of GHG, preventing global warming, achieving rural development and finally providing conditions to attain sustainable development.

\footnotetext{
${ }^{8}$ Distributed generation plants are built at the consumption site so they do not require any transmission network and aggregation of scattered villages.
} 
The country is facing many serious challenges for the RE development. It seems that an innovative policy making is required to deal with the challenges of the non-proliferation of the RE development. With regard to challenges for the RE development a combination of some policy instruments such as below is necessary for the promotion of renewable energy:

- Phase out fossil fuel subsidies to fund the required incentive mechanisms for renewable energy;

- Put in place more incentive mechanisms for renewable energy technologies;

- Use international climate finance efficiently and effectively by unlocking and leveraging much greater volumes of private capital;

- Mitigate political and regulatory investment risk;

- Increasing Direct investment in R\&D;

- Raising public awareness about negative effect of fossil fuel consumption by education and information broadcasting system to increase social acceptance.

\section{Acknowledgments}

The authors wish to thank Bethany Gardner from the Department of Linguistics, Binghamton University for her kind help in improving the English of this text.

\section{References}

[1]Ahmadi R, Kiadaliri H,Mataji A,Babaee Kafaki S. Oak forest decline zonation using AHP model and GIS technique in Zagros forests of Ilam province. Journal of Biodiversity and Environmental Sciences (JBES) 2014; 4(3): 141-150.

[2] Alamdari P, Nematollahi O, Mirhosseini M. Assessment of wind energy in Iran: A review. Renewable and Sustainable Energy Reviews 2012; 16: 836 - 860.

[3] Alamdari P, Nematollahi O, Alemrajabi AA. Solar energy potentials in Iran: review. Renewable and Sustainable Energy Reviews 2013; 21: 778-788.

[4] Ali Beigi AH, Poor Morady A, Afshar Zade N. Predictors of agricultural science students' choice of careers in agriculture: A case from Kermanshah Province, Final report of research project, Razi University, Kermanshah, Iran, 2011.

[5] Anonymous. British Petroleum statistical review of world energy; 2013. Available from: www. bp.com/ statistical review.

[6] Ansari B, Mirdamadi SM, Farajollah Hosseini SJ, Noorollahi Y. Barriers and constraints facing the application of biomass resources (Livestock Residues) in rural areas of Iran (Case Study: Tehran Province). Advances in Environmental Biology 2013; 7(9): 2091-2099.

[7] Ardehali MM. Rural energy development in Iran: Non-renewable and renewable resources. Renewable Energy 2006; 3: 655-662.

[8] Asakereh A, Shiekh Davoodi MJ, Akram A. Investigation of energy consumption in agriculture sector of Iran and their effect on air pollution and social cost. Research Journal of Applied Sciences Engineering and Technology, 2010; 2 (5): 401- 406.

[9] Aslani AR, Naaranoja M, Antila E. The feasibility study of prior renewable energy alternatives to private sector investment. International Journal of advanced Renewable Energy Research 2012a; 1(5):248- 253.

[10] Aslani AR, Naaranoja M, Zakeri B. The prime criteria for private sector participation in renewable energy investment in the Middle East (Case Study: Iran). Renewable and Sustainable Energy Reviews 2012b; 16: 1977- 1987.

[11] Atabi F. Energy in Iran: Challenges and opportunities for sustainable development. International Journal of Environment Science and Technology. 2004; 1(1): 69-80. 
[12] Azadi H, Ho P, Hasfiati L. Agricultural land conversion drivers: A comparison between less developed, developing and developed countries. Land Degradation \& Development 2011; 22: 596 604.

[13] Bagher Zadeh A, Amir Taimuri S. Estimate the energy demand of the agricultural sector. In: 7th national conference on energy, Tehran, Iran, December 22 - 23, 2009.

[14] Bahrami A, Emadodin I , Ranjbar Atashi M , Rudolf Bork H. Land-use change and soil degradation: A case study North of Iran. Agriculture and biology journal of North America 2010; 1(4): 600-605.

[15] Bahrami M, Abbas Zadeh P. An overview of renewable energies in Iran. Renewable and Sustainable Energy Reviews 2013; 24:198-208.

[16] Bani Hashmi SAR. Copenhagen summit and its impact on agriculture. Environment and Sustainable Agricultural Development Department and Agricultural Research \& Extension Organization, 2009.

[17] Barnett, J. Dessaib, S. Climate Policy. Viewpoint. Articles 4.8 and 4.9 of the UNFCCC: Adverse effects and the impacts of response measures 2002; 2: 231-239.

[18] Bloomberg New Energy Finance, 2013.

[19] Clement A, Mc Cullen P, Falcao A, Fiorentino F, Gardner F, Hammarlund K. Wave energy in Europe: Current status and perspectives. Renewable Sustainable Energy Review 2002; 6:405-31.

[20] Derakhshan S, Nourbakhsh A. Experimental study of characteristic curves of centrifugal pumps working as turbines in different specific speeds. Experimental, Thermal and Fluid Science Journal 2008; 32:800-807.

[21] Energy Balances, Power and Energy Planning Department, Ministry of Energy of I.R.IRAN.2010.

[22] Energy Balances, Power and Energy Planning Department, Ministry of Energy of I.R.IRAN.2011.

[23] Energy Sector, Office of Investigations and policies of Central Bank of the Islamic Republic of Iran. Efficiency and energy intensity in Iran and the World, 2010.

[24] Emadodin, I. Human-induced soil degradation in Iran. In: Ecosystem services workshop, Salzau Castle, Germany, May, 13 - 15, 2008.

[25] Eskafi F. Energy consumption and GHG emissions in the transportation sector of Iran. In: 16Th reform group meeting, Salzburg, September 2, 2011.

[26] FAO. Global forest resources assessment. 2010.

[27] FAO/GBEP. A review of the current state of bioenergy development in G8 +5 Countries. 2008.

[28] Gaye A. Access to energy and human development. Human Development Report. 2007/2008.

[29] German Watch and Climate Action Network Europe. Climate Change Performance Index.2013.

[30] Ghazi Zade, M. Elahi,S. Asnavandi A. Reliable policy making: A new approach to production and supply electricity from renewable energy resources. Final report of research project, Shahid Abbaspour University, Tehran, Iran. 2008.

[31] Ghadimi A, Razavi F, Mohammadian B. Determining optimum location and capacity for micro hydropower plants in Lorestan province in Iran. Renewable and Sustainable Energy Reviews 2011; 15: 4125-4131.

[32] Ghamarnia H. Mosa Begay, F. Amiri S. Solar energy potential in Kermanshah province. In: 3rd annual scientific conference of Razi University, Kermanshah, Iran, November, 2012.

[33] Ghorashi AH, Rahimi A. Renewable and non-renewable energy status in Iran: Art of know-how and technology-gaps. Renewable and Sustainable Energy Reviews 2011; 15:729-36.

[34] Golabi Z. The role of energy sector in sustainable development in Iran. Ms Thesis. Massachusetts Institute of Technology, 2011.

[35] Habibi M, Dry and Empty. Sunshine Network Journal. 2013; 13:2-4.

[36] Hale S. The new politics of climate change: Why we are failing and how we will succeed. Environmental Politics 2010; 19: 255-275.

[37] Hamzehee MR, Fazel Beygi MM. From underdevelopment to sustainable development. Volume 2. Kermanshah: Razi University Press. 2011.

[38] Helio International, Sustainable Energy Watch. Energy and sustainable development in Iran. 2005/2006.

[39] Hoekstra AY, Chapagain AK. Water footprints of nations: Water use by people as a function of their consumption pattern. Water Resource Management. 2007; 21:35-48. 
[40] IEA (International Energy Agency). World energy outlook. Paris: OECD/IEA. 2009.

[41] IEA (International Energy Agency). World energy outlook. Paris: OECD/IEA. 2010.

[42] Iran Energy Facts and Figures. Power and Energy Planning Department. Ministry of Energy, I.R. Iran. 2009.

[43] Iran Environment and Wildlife Watch, 2012.

[44] Karbassi AR, Abduli MA, Mahin Abdollah Zadeh E. Sustainability of energy production and use in Iran. Energy Policy 2007; 35: 5171-5180.

[45] Kardony R. Importance of renewable energies in Iran, Middle East Institute for Strategic Studies. 2013.

[46] Kardowani P. Drought and ways to fight it in Iran. Tehran: Tehran University Press. 2001.

[47] Khodadad Kashy F, Heydari Kh. Measurement of poverty indicators in Iran (application of the poverty line, the poverty gap and poverty index. Institute of Statistical Center of Iran. 2000.

[48] Khojaste Mehr M. Preservation of energy resources, today's necessity, tomorrow's need. Journal of Exploration \& Production Oil \& Gas. 2010; 68:6-8.

[49] Khosroshahi M, Karami SA.A. Method to identify and separate the desert areas at climatology perspective (Case study of Tehran province). Journal of Range and Desert Research 2003; 1 (10):3955 .

[50] Lashkari Poor G, Rostami Barany HR, Kohandel A, Torshizi, H. Decline in groundwater levels and land settlement in Kashmar plain. In: 10th Symposium of Geological Society of Iran, Tarbiat Modares University,Tehran, Iran. 2006.

[51] Lechtenbohmer S, Prantner M, Sefried D, Supersberger N, Moshiri S, Atabi F, Panjeshahi MH. Feed in laws and other support schemes in international perspective. Wuppertal institute \& Iran Energy Association. 2010.

[52] Majlis Research Center (MRC). Impact of energy price reform on energy and non energy demand in the household sector, 2012.

[53] Makhdoom Farkhondeh M. Overview of the environment: Conditions and trends. Environmental Research 2013; 8: 37 - 42.

[54] Marandi A, Dehdashtian M. Biogas feasibility study in Iran. Proceedings of second national energy conference, Tehran, Iran, 1999.

[55] Massarrat M. Iran's energy supply: Capacities, requirements and options for the future. By order of Angelika Beer and the greens European free alliance in the European parliament, 2007.

[56] Mazandaranian A, Mahliaa TMI, Chonga WT, Moghavemi M. A review on the pattern of electricity generation and emission in Iran from 1967 to 2008. Renewable and Sustainable Energy Reviews 2010; 14(7):1814-29.

[57] Ministry of Energy (MOE). Development of renewable energy applications in power generation industry by environmental and economic approach. 2012.

[58] Ministry of Energy (MOE). 2015. http://www. moe.ir

[59] Ministry of Agriculture Jihad. 2012. http://www. maj.ir

[60] Ministry of Petroleum.2013.http://www.mop.ir

[61] MirakzadeA, Afsharzade N, Ghambar Ali R, Geravandi Sh, Moradi Kh, Zarafshani K. Investigation problems of procurement, modernization and integration land plan in Meyan Darband plain, Kermanshah city. Final report of research project, Razi University, Kermanshah, Iran. 2011.

[62] Mostafaeipour A, Abarghooei H. Harnessing wind energy at Manjil area located in North of Iran. Renewable and Sustainable Energy Reviews 2008; 12: 1758-1766.

[63] Najafi Gh, Ghobadian B. Geothermal resources in Iran: The sustainable future. Renewable and Sustainable Energy Reviews 2011a; 15: 3946-3951.

[64] Najafi Gh, Ghobadian B. Wind energy resources and development in Iran. Renewable and Sustainable Energy Review 2011b; 15(6):2719-2728.

[65] Noori Esfandyari A. Groundwater: The visible that is invisible. Journal of dialogue of water. 2011; $3: 3$.

[66] Noorollahi Y, Yousefi H, Ehara S, Itoi R. Geothermal energy development in Iran. In: Direct heating use of geothermal resources in Asia workshop, Tianjin, China; May, 11-18, 2008. 
[67] National Energy Panel. Necessities and strategies to development distributed generation power. Journal of Energy Economics, 2009; 121: 21-27.

[68] Papzan AH, Heidari H. Energy Parks: A mechanism for public education. In: 2nd Iran's bioenergy conference; Tehran, October 21, 2011.

[69] Papzan AH, Papzan A. CO2 emission reduction by using renewable energy in Iran: Towards sustainable development. Journal of American Science 2012; 8(7):427-434.

[70] Payame Tabiat. Magazine of Iranian Forest Rangeland and Watershed Organization 2012:87-88.

[71] Payame SUNA. Report 4. Biomass. 2010.

[72] Planning Department of the Ministry of Petroleum. Journal of Exploration and Production Oil and Gas. 2013: 94.

[73] RCRA (Research Core of rural architecture). The use of renewable energy in housing and rural development. Final report of research project, Shahid Beheshti University, Faculty of Architecture and Urbanism, 2009.

[74] Renewable Energy Policy Network for the 21st Century (REN21). Energy for Development: The potential role of renewable energy in meeting the Millennium Development Goals. World watch Institute, Washington DC. 2005.

[75] Saboori BA, Soleymani A. CO2 emission, economic growth and energy consumption in Iran: A cointegration approach. International journal of Environmental Sciences 2011; 2(1): 44-52.

[76] Sadegh Zade SM. The energy crisis and the opportunities ahead. Energy Economics journal. 2009; 120:25-28.

[77] Sala OE, Chapin IFS, ArmestoJJ, Berlow E, Bloomfield J, Dirzo R, Huber Sanwald E, Huneke F, Jackson RB, Kinzing A, Leemans R, Lodge D H, Mooney H A, Oesterrheld M, Leroy Poff N, Sykes MT, Walker BH, Walker M, WallD H. Global biodiversity scenarios for the year 2100. Science 2000; 287:1770-1774.

[78] Samadi SH, Ghobadian B, Najafi Gh. Construction biogas combined heat and power plants (CHP) from dairy industry in Iran. 3rd congress of bioenergy (Biomass and Biogas).Tehran, Iran. January, 2012.

[79] Sarlak H, Seif MS, Abbaspour M, Abshenas S. Towards renewable energy development, A ModelStudy in ocean electricity generation. In: $24^{\text {th }}$ international power system conference. Tehran, Iran, November, 2009.

[80] Sartipi Poor M. The role of renewable energy in rural development. Journal of Geography. 2011; 9 (31):125-148.

[81] Shabanali Fami H, GhasemI J, Malekipoor R, Rashidi P, Nazari S, Mirzaee A. Renewable energy use in smallholders farming systems: A Case study in Tafresh Township of Iran. Sustainability. 2010. 2: $702-716$.

[82] Shafiee S, SabooriDaylami MH. The necessity of reviewing methods of energy production and consumption in Iran's economy. Investing Economic Issues and Policies Journal 2009; 11\&12:21-42.

[83] Shafi Pour MM, Farsiabi MM. An environmental economic analysis for reducing energy subsidies. International Journal of Environmental Research 2007; 1 (2):150 -1.

[84] Shukla A. Study of technological, economical and social aspects to energies off-grid regions through distributed generation in developing countries. Doctoral Dissertation. Osnabrück University, 2007.

[85] Singh V, Fehrs J. The work that goes into renewable energy. Renewable Energy Policy Project (REPP), Washington D.C.2001; 13, 28.

[86] Soori F. Biogas, wealth latent in waste. Rah Shahr Scientific, Technical and Engineering Journal. $2010 ; 116: 4-32$.

[87] Strategic Research Center of the Expediency Council. Department of Energy Economics. Energy economics in rural areas, 2007

[88] SUNA (Iran Renewable Energy Organization). Renewable energy in Islamic Republic of Iran: Policy potential energy security private sector application. In: Energy security seminar, Salzburg, Austria. September, 21-24, 2010. 
[89] Terrados J, Almonacid G, Perez H. Proposal for a combined methodology for renewable energy planning, Application to a Spanish region. Renewable and Sustainable Energy Reviews 2009; 13: 2022-2030.

[90] Troster E, Kuwahata R, Ackermann T. European grid study. Technical report. Langen, Germany: Energy nautics GmbH. 2011.

[91] UCLA Institute of the Environment and Sustainability and Anderson School of Management. US State. Policies for renewable energy: Context and effectiveness. 2013.

[92] UNDP (United Nations Development Programme). Fighting climate change: Human solidarity in a divided world. Human development report office occasional paper, 2008.

[93] UNEP (United Nations Environment Programme). Global green new deal, Policy brief. 2009.

[94] UNEP (United Nations Environment Programme), ITC (International Trade Center), ICTSD (International Center for Trade and Sustainable Development). Green economy and trade opportunities. 2012.

[95] UNEP (United Nations Environment Programme). Low carbon green growth roadmap for Asia and the Pacific (Case Study: China's renewable energy policies). 2014.

[96] UN General Assembly, Session. Promotion of new and renewable sources of energy. 2011.

[97] United States Institute to Peace. Iran's environment: Greater threat than foreign foes.

[98] Van der Werf GR, Morton DC, De Fries RS, Olivier JGJ, Kasibhatla PS, Jackson R B, Collatz GJ, Randerson J T. CO2 emissions from forest loss. Nature geoscience 2009; 2:737-738.

[99] World Bank. Islamic republic of Iran: Cost assessment of environmental degradation. Middle East and North Africans region. Report No. 32043-IR. Washington DC, 2005.

[100] World Economic Forum. The Global Energy Architecture Performance Index Report, 2014.

[101] Yale Center for Environmental Law and Policy, Yale University. Environmental Performance Index and pilot trend, Full report. Yale Center for Environmental Law and Policy, Yale University Center for International Earth Science Information Network, Columbia University In collaboration with World Economic Forum, Geneva, Switzerland Joint Research Centre of the European Commission, Ispra, Italy. 2012. Available at the EPI website: www.epi.yale.edu.

[102] Yosefshahi M. Death of plain. Irrigation Magazine. 2010; 62:24-27.

[103] Yagwitz M, Rathmann M. Renewable energy policies in the EU member states indicators assessing market status, Policy effectiveness and efficiency. Supported by intelligent energy Europe. 2012.

[104] Zandi R, Petrovic U. Climate change and role of geography in most polluted city in the world (Ahwaz). In: 2nd national conference on planning and environment protection, Tehran, Iran, December, 31, 2013.

[105] Zohoori M. Exploiting renewable energy sources in Iran. Interdisciplinary Journal of Contemporary Research in Business. November 2012; 4(7):849-862.

[106] Zoser H, Altman J, Egg F, Granata A, Board R. Development and integration of renewable energy: Lessons learned from Germany. FAA (Financial Advisory AG).2014. 


\section{Acronyms}

\begin{tabular}{|l|l|}
\hline TAVANIR & $\begin{array}{l}\text { Iran Power Generation Transmission and Distribution } \\
\text { Management Company }\end{array}$ \\
\hline GHG & Green House Gas \\
\hline RE & Renewable Energy \\
\hline MOE & Ministry Of Energy \\
\hline UN General Assembly & United Nations General Assembly \\
\hline RETs & Renewable Energy Technologies \\
\hline R\&D & Research and development \\
\hline RES & Renewable Energy Systems \\
\hline EU & European Union \\
\hline FITs & Feed-In Tariffs \\
\hline SUNA & Iran Renewable Energy Organization \\
\hline CCPI & Climate Change Performance Index \\
\hline MDGs & Millennium Development Goals \\
\hline
\end{tabular}

